\title{
The "SUPER" Program to Increase Marital Satisfaction
}

\author{
Ika Rizki Ramadhani, Tina Afiatin ${ }^{2}$ \\ Faculty of Psychology, Universitas Gadjah Mada \\ Submitted 16 March 2020 \\ Accepted 7 July 2020 \\ Published 28 October 2020
}

\begin{abstract}
A successful marriage can be achieved by aiming for a satisfying marriage. The low level of marital satisfaction causes various problems in marriage that might lead to divorce. The aim of this study was to determine the effect of the "SUPER" program in increasing marital satisfaction. The "SUPER" program is a gratitude intervention based on techniques of building sense of gratitude. Participants in this study were 12 married women with marriage period ranging from 1 to 10 years who were divided into two groups: 6 women in experimental group and 6 women in control group). The experiment in this study used untreated control group design with pretest-posttest and analyzed using MannWhitney $U$ test. Data analysis results showed that there was significant difference in marital satisfaction scores between experimental and control group $(Z=-2.098, p<0.05)$. The Wilcoxon Signed-rank test conducted on experimental group found that there was significant increase in marital satisfaction score from pretest to posttest $(Z=-1.992, p<0.05)$. Therefore, it can be concluded that the "SUPER" program can increase marital satisfaction in married women. Marital satisfaction aspects that had increased were cognitive, interaction patterns, social support, and physiological aspects. Cognitive aspect had the highest score increase compared to other aspects.
\end{abstract}

Keywords: gratitude; marital satisfaction; SUPER program

A successful, happy, and quality marriage is a dream of every married couple. Marriage happiness and success can be achieved by aiming for satisfying marriage. One of important things in married life is achieving marital satisfaction (Papalia, Olds, \& Feldman, 2008). Marital satisfaction plays an important role in married life, including maintaining physical (Stone \& Shackerlford, 2007) and psychological wellbeing of married individuals (Proulx, Helms, \& Buehler, 2007; Cohen, Geron, \& Farchi, 2009). Satisfactory marital condi-

${ }^{1}$ Address of correspondence:

ika.rizki.r@mail.ugm.ac.id'

²or afiatin04@ugm.ac.id tions make individuals less susceptible to stress, both psychologically and physically (Gove, Style, \& Hughes, in Santrock, 2006). Marital dissatisfaction has a negative impact on individuals, both physically and psychologically, such as causing anxiety and depression (Omani-Samani, Maroufizadeh, Ghareri, Amini, \& Navid, 2018). The dissatisfaction in marriage might eventually lead to divorce (Afni \& Indrijati, 2011).

According to Stone and Schackerlford (2007), marital satisfaction is defined as a mental condition that represents advantages and disadvantages perceived by individuals in their marital life. Preliminary study results found an 
overview of marital dissatisfaction at the beginning of marriage is indicated by feeling disappointment due to discrepancy between expectation and reality of marital relations which is also known to affect marital satisfaction at the early age of marriage. This condition makes individual perception of their partner's role in fulfilling their responsibilities as husband or wife become negative (Strong et al., 2011).

Marital dissatisfaction caused by individual perception in which they compare their conditions with others, including their ideal imaginations (Linley \& Joseph, 2004), discrepancy between expectation and reality, and unfulfilled marital relations needs. Furthermore, satisfaction is also affected by individual perception to stay focused on their satisfying experience or not (Linley \& Joseph, 2004). Individual perceived satisfaction depends on their evaluation of events or experiences. If an individual is able to assess and evaluate an event from positive perspective, it can be deduced that they presume by having positive perception or perspective is important to be able to feel satisfaction, thus this will be the focus of this study.

Changing individual cognitive appraisal of their relationship to be more positive is considered important because it might affect their overall relationship satisfaction (Baucom \& Epstein, 1991). Changing appraisal as cognitive evaluation potentially helps individuals in increasing their marital satisfaction because then they will be able to evaluate negative situations from positive perspective, for example to appreciate their partner more. Gratitude can be used to divert negative appraisals and thoughts to be positive ones (Emmons \& Stern, 2013), including in marital relationships. Replacing negative appraisals and thoughts into gratitude can make individuals to have positive appraisal of their partner and marital relationship. Grateful individuals will focus more on positive attributes and matters of their partner (McCullough, Tsang, \& Emmons, 2004). Thus, it can be concluded that gratitude affects marital satisfaction. Therefore, to overcome the discrepancy, individuals need to be provided with knowledge and ability to have a positive appraisal with gratitude. Gratitude intervention is expected to generate gratitude in individuals. Gratitude intervention used in this study is the "SUPER (Syukur dalam Perkawinan/Gratitude in Marriage)" program. The main fundamental of the "SUPER" module is to generate gratitude in individuals by increasing one's understanding, skills, meaning, and level of gratitude.

This study aimed to determine the effect of the "SUPER" Program in increasing marital satisfaction in married women. Previous studies have examined gratitude intervention and its effect on increasing marital adjustment (Ni'mah, 2014) and marital satisfaction (Maulina, 2015). The difference between this study with previous ones lies in the study location and instruments used in the studies. Maulina (2015) did the study in Aceh Province, whilst this study is conducted in Yogyakarta. The difference in location is considered important due to cultural and subject characteristic difference, thus it is 
expected to provide different results. This study also used different instruments that vary from previous studies e.g., measuring instruments and training modules.

\section{Method}

The dependent variable in this study is marital satisfaction in married women. The definition of marital satisfaction used in this study is individual subjective evaluation of their overall marital life which is based on advantages and disadvantages perceived by individuals as well as their appraisal of their marital life.

The independent variable in this study is the "SUPER" program. The "SUPER" program used as an intervention applies four techniques for creating and strengthening gratitude in individuals as proposed by Watkins (2014) i.e., (a) recounting; (b) reflection; (c) expression; (d) reappraisal. Various activities in the "SUPER" program will upskill individuals to have positive appraisal towards their married life and pay more attention to simple things that happen in life. Individuals will perceive their marriage in a positive perspective and rarely feel deprived of their relationships when they have gratitude (Lambert et al., 2009). That way, when individuals re-evaluate their marital relationship and perceive more advantages than disadvantages, their marital satisfaction will increase.

Participants of this study were 12 married women who were divided into two groups; 6 participants in the control group and 6 participants in the experimental group. Subject characteristics were as follows (a) married women with marriage age of 1-10, (b) had moderate and low in marital satisfaction scale, (c) previously never received gratitude intervention and not in the middle of any psychological intervention process, (d) had good reading and writing skills, (e) willing to carry out activities and assignments throughout the program.

Data collection in this study was using Marital Satisfaction Scale. The scale was given three times to measure marital satisfaction score: pretest, posttest, and follow up. Marital Satisfaction Scale in this study was composed by researchers with regard to marital satisfaction aspects by Stone and Shackerlford (2007) which consisted of cognitive, physiological, interaction patterns, social support, and violence aspects. There were 21 items that consisted of favorable and unfavorable items. This scale used five answer choices i.e., STS (Sangat Tidak Sesuai/Strongly Irrelevant), TS (Tidak Sesuai/Irrelevant), N (Neutral), S (Sesuai/Relevant), and SS (Sangat Sesuai/Strongly Relevant). Reliability coefficient of Marital Satisfaction Scale was measured at 0.947 .

Researchers measured participants' level of satisfaction as a manipulation check. Manipulation check aims to ensure each intervention is achieved as desired. Instrument used as manipulation check was Indonesian version of Gratitude Scale (Skala Bersyukur) composed by Listiyandini et al. (2015). The scale was structured based on three gratitude components proposed by Watkins et al. (2003) and Fitzgerald (1998) i.e., sense of appreciation, positive feeling of life, and gratitude expression. The scale had been through psychometric testing and passed validity and reliability tests. Its 
reliability coefficient was 0.8 with internitems correlation coefficient moved between $0.3-0.6(r=0.3-0.6)$. The scale was consisted favorable and unfavorable items with total of 30 statement items. The scale was used Likert model with six answer choices i.e., STS (Sangat Tidak Sesuai/Strongly Irrelevant), TS (Tidak Sesuai/Irrelevant), ATS (Agak Tidak Sesuai/Slightly Irrelevant), N (Neutral), S (Sesuai/Relevant), and SS (Sangat Sesuai/Strongly Relevant).

Experimental design used in this study is untreated control group design with pretest and posttest (Shadish, Cook, \& Campbell, 2002) as described in Table 1.

Statistical descriptive analysis showed average pretest score of marital satisfaction for experimental group and control group were at 68 and 75.5. After that, the difference of pretest score was measured to ensure both groups were in an equal condition before intervention was given. Data analysis results showed that variance of both groups was in equal condition with $p=0.361 \quad(p>0.05)$. The hypothesis in this study was tested using Mann Whitney U and Wilcoxon signed ranks tests. Mann Whitney $U$ test analysis started with counting gain score or marital satisfaction score difference of each participant. It was

Table 1.

Study Design

\begin{tabular}{llcccc} 
& \multicolumn{1}{c}{ Group } & Pretest & Intervention & Posttest & Follow-up \\
\cline { 2 - 5 } $\mathrm{NR}$ & \multicolumn{1}{c}{$\mathrm{KE}$} & $\mathrm{O}_{1}$ & $\mathrm{X}$ & $\mathrm{O}_{2}$ & $\mathrm{O}_{3}$ \\
& \multicolumn{1}{c}{$\mathrm{KK}$} & $\mathrm{O}_{1}$ & - & $\mathrm{O}_{2}$ & - \\
\hline $\mathrm{NR}$ & : Non-Random & & \\
$\mathrm{KE}$ & : Experimental group who received intervention & \\
$\mathrm{KK}$ & $:$ Control group who did not receive intervention & \\
$\mathrm{O} 1$ & $:$ Pretest & & \\
$\mathrm{O} 2$ & $:$ Post-test & & \\
$\mathrm{O} 3$ & $:$ Follow-up & & \\
$\mathrm{X}$ & : Intervention or the “SUPER" Program & & \\
- & : No intervention & &
\end{tabular}

The Mann-Whitney U and Wilcoxon Signed-rank tests were used to analyze data in this study. The Mann-Whitney test was used to examine score difference of both groups i.e., experimental group and control group, whereas Wilcoxon test was used to examine marital satisfaction score difference of experimental group between pretest and posttest.

\section{Results}

found that $U$ score at 5.00 with $Z=-2.089$ and $p=0.037 \quad(p<0.05)$. The results showed there was significant gain score between control group and experimental group, thus it can be concluded that the "SUPER" program can affect marital satisfaction in married women.

Based on Wilcoxon test results shown in table 2, it can be seen that there was significant difference in level of marital satisfaction between posttest and pretest 
score in experimental group with $Z=-1.992$ and $p=0.046(p<0.05)$. Thus, the hypothesis in this study was accepted; the "SUPER" program can increase marital satisfaction. and after the program. Therefore, it can be concluded that the "SUPER" program can increase marital satisfaction in married women. This study reaffirms previous

Table 2.

Summary of Wilcoxon Test

\begin{tabular}{clcc}
\hline Group & Measurement & Z & Sig. \\
\hline Experimental & Posttest-Pretest & -1.992 & 0.046 \\
& Follow up-Posttest & -1.483 & 0.138 \\
Control & Posttest-Pretest & -0.542 & 0.588 \\
\hline
\end{tabular}

Follow up was done one week after the program was completed. The results of follow up using Wilcoxon test to six participants in experimental group showed no significant marital satisfaction score increasement between posttest and follow up with $Z=-1.483(p>0.05)$. On the other hand, table 2 also showed that there was no significant difference between posttest and pretest in control group $(Z=0.542(p>0.05))$.

Furthermore, Wilcoxon test was conducted to determine posttest and pretest gratitude score difference of experimental group. Wilcoxon test for experimental group showed $Z$ score at -2.207 with $p=0.027(p<0.05)$. It showed that there were score difference between pretest and posttest of experimental group. Therefore it can be concluded that the change in marital satisfaction score in experimental groups was caused by intervention.

\section{Discussion}

Based on the result of Mann Whitney $U$ test, it was found that there was a marital satisfaction score difference between control and experimental groups. There was a significant marital satisfaction score increase in the experimental group before studies by Algoe et al. (2010), Mitchell (2010); and Parnell (2015) which found that gratitude intervention is proven to be able to increase marital satisfaction.

Marital satisfaction comes from individual subjective evaluation of their marriage relation; it reflects how much they perceived advantages and disadvantages of their marriage relation as well as how much they appreciate their marriage (Stone \& Shackerlford, 2007). Individual gratitude increases sensitivity and awareness of positive things (Gordon \& Baucom, 2009) and makes them feel sufficient, does not feel deprived, and has more positive thoughts ((Lambert, Fincham, Braithwaite, Graham, \& Beach, 2009; Watkins, Woodward, Stone, \& Kolts, 2003). A grateful individual will have motivation to repay kindness they have received from others as a form of appreciation. Therefore, the more grateful individual is, the higher level of marital satisfaction they feel.

Aside from marital satisfaction score increase, researchers also examined changes in every aspect of marital satisfaction. Data analysis results showed that gratitude intervention in the "SUPER" program can increase four marital 
satisfaction aspects, while the other five aspects do not change.

The "SUPER" program can increase cognitive aspect of marital satisfaction. It means that gratitude intervention is able to make individuals have more positive appraisal towards their partner and married life. The more positive appraisal, the higher level marital satisfaction of an individual. It reaffirms a study by Mitchell (2010) which found that individual cognitive appraisal towards their partner's behavior, both positive and negative, prone to be able to direct their partner's behavior according to their appraisal; thus, it will also influence the appraisal of their marital relationship.

Feeling of disappointment due to discrepancy between expectation and reality in individual's married life affects their marital satisfaction (Vanlaningham, Johnsin, \& Amato, in Strong et al., 2011). Disappointment in marriage is considered by many participants to have negative and pessimistic outlooks of the future of marriage. Cognitive element of gratitude that makes individuals shift negative appraisal to positive ones (Emmons, 2007) can help individuals to have a more optimistic outlook. This condition is experienced by all participants as indicated by having a more optimistic outlook of their marital relations after participating in the "SUPER" program. Individuals with positive future outlook no longer think of separation and regret while having a more positive outlook of their future marital relations. This condition is in accordance with findings from Mitchell (2010) that positive appraisal is beneficial for marital relation because individuals or partners will have a more optimistic future of their marriage thus it can ultimately increase marital satisfaction.

Emotional element in gratitude focuses on fascination, gratefulness, and appreciation for the good things in life (Emmons, 2007). Adjust and practice oneself to be grateful are known to increase positive emotions and decrease negative emotions (Mccullough et al., 2002). It is also related with the interaction pattern aspect of marital satisfaction. Gratitude can present positive emotions which will increase interaction and communication quality between individuals, and also increase couple intimacy which is manifested in the increasing tendency of individuals to engage in activities with their partner (Mitchell, 2010; Coulter \& Malouff, 2013; Parnell, 2015; Davis et al., 2016; Drążkowski, Kaczmarek, \& Kashdan, 2017).

Conflicts that occur in marital relationships undeniably will have an impact on marital satisfaction (Canel, 2013). If neither individual or their partner have good ability of conflict management, their marriage stability will be vulnerable. Couples with high level of marital satisfaction are inclined to use the right way to solve their problems (Olson, DeFrain, \& Skogrand, 2013). Prolonged conflicts and ineffective ability of conflict management as well as communication style in problem solving are found to affect participants' marital satisfaction of this study (Canel, 2013, Zaheri et al., 2016). The presence of children is also known to affect marital satisfaction (Hirschberger et al., 2011, Strong et al., 2011). Problems related to childcare are often the source of conflict between married couples (Olson et al., 
2013). Perspective differences in educating and nurturing children oftentimes create disagreement between married couples, thus affecting their marital satisfaction. However, the presence of children can positively affect marital satisfaction. If married couples have an agreement on childcare, it can increase their marital relationships quality (Wahyuningsih, 2012).

Individuals who have many conflicts in their marriage prone to feel uncomfortable with their marital relationship patterns. Qualitative data analysis results found that gratitude can produce comfort in individuals' married life. This is in accordance with findings from Barton et al. (2015) that expressing gratitude is able to nullify the negative impact of marital conflict. Individuals will feel more positive emotion in oneself than negative emotion by expressing gratitude (McCullough et al., 2002). Positive emotion creates individual comfort in interaction with their partners. Individual comfort allows them to find positive ways to solve their problem such as discussion (Lambert \& Fincham, 2011), to communicate with close related people, to seek help and support from close related people, and to plan for problem solving (Wood, Joseph, \& Linley, 2007).

In practice, this program is carried out in a group intervention setting which facilitates members to interact with each other. Interaction between members or between the trainer and members is able to support the therapeutic change process. The use of experiential learning is considered effective and contributes to the success of the program where individuals will learn from their own experience.
The success of the "SUPER" program cannot be separated from the trainer who was able to convey positive values of the program appropriately to participants. The trainer was a psychologist who has experience in psychological interventions. Participants assessed the trainer as someone who was able to understand participants' psychological conditions and able to facilitate them in developing more positive feelings and attitudes. Trainer's mastery in presenting and delivering program material which is easily understood by participants also makes this program successful in increasing participants' marital satisfaction.

On the other hand, this study has several limitations. First, there was no randomization in deciding participants' group placement i.e., experimental group and control group. This could affect the internal validation score of the study. However, researchers already anticipated this condition by conducting homogeneity test or subject equality towards marital satisfaction score as dependent variable before the program began. Both groups were in an equal condition before the program began.

Second, the limitation comes from maturation factor or participants' maturity. Maturity is related to participants' biological and psychological changes that are considered to affect dependent variable in the study (Azwar, 2017). Researchers had anticipated by presenting control group as comparison group. The third comparison is testing factor. Testing is referred as repeated measurements, three times in experimental group and two times in control group, which made the possibility 
of learning effect because participants were familiar with the scale. Researchers' anticipated this condition by giving instruction to answer it according to their condition at that moment. Aside from that, this study used non-parametric analysis method, so that the results cannot be generalized.

The success of this program was also influenced by trainer's role and ability to deliver the program. The trainer was a psychologist who experienced psychological interventions and had specific ability and skills in carrying out intervention processes e.g., counseling and therapy. This could be a limitation for implementation of this program. Trainer for this module implementation needs to have the same characteristic with trainer characteristic in this study because trainer characteristic differences could give different results.

\section{Conclusion}

Findings of this study indicated that gratitude intervention in the "SUPER" program is proven to be able to increase marital satisfaction in married women. Data analysis results showed several factors that affect marital satisfaction i.e., appreciation, communication style, emotional stability and regulation, presence of children, and conflict resolution. Various techniques to be grateful that have been done in the "SUPER" program can increase various marital satisfaction aspects i.e., cognitive, interaction pattern, social support, and physiological aspects. Cognitive aspect has the most noticeable increment score compared with other marital satisfaction aspects.

\section{Suggestion}

Study participants are advised to implement new knowledge and skills from the intervention process in their marital life, such as applying techniques to be grateful and adjusting oneself to think positively with gratitude. These things were informed to participants at the end of the intervention process.

Future study can consider randomization in determining study participants. It is also important to create an intervention timeline before the screening process so that participants can provide their time and fully participate in the intervention process from beginning to the end; thus participants placement in the study can be done randomly which results in a high internal validity score.

\section{References}

Afni, N., \& Indrijati, H. (2011). Pemenuhan aspek-aspek kepuasan perkawinan pada istri yang menggugat cerai. Insan Media Psikologi, 13(3), 176-184.

Algoe, S. B., Gable, S. L., \& Maisel, N. C. (2010). It's the little things: everyday gratitude as a booster shot for romantic relationships. Personal Relationships, 17(2), 217-233. doi: http://dx.doi.org/10.1111/j.14756811.2010.01273.x

Azwar, S. (2017). Metode penelitian psikologi (2nd edition). Yogyakarta: Pustaka Pelajar

Barton, A. W., Futris, T. G., \& Nielsen, R. B. (2015). Linking financial distress to 
marital quality: the intermediary roles of demand/withdraw and spousal gratitude expressions. Personal Relationships, 22(3), 536-549. doi: http://dx.doi.org:10.1111/pere.12094

Baucom, D. H., \& Epstein, N. (1991). Will the real cognitive behavioral marital therapy please stand up? Journal of Family Psychology, 4(4), 394-401. doi: https://doi.org/10.1037/08933200.4.4.394

Canel, A. N. (2013). The development of the Marital Satisfaction Scale (MSS). Kuram ve Uygulamada Eğitim Bilimleri, 13(1), 97-117.

Cohen O., Geron Y., Farchi A. (2009). Marital quality and global well-being among older adult Israeli couples in enduring marriages. The American Journal of Family Therapy, 37(4), 299317. doi: http://doi.org/10.1080/019261808024059 $\underline{68}$

Coulter, K., \& Malouff, J. M. (2013). Effects of an intervention designed to enhance romantic relationship excitement: a randomized-control trial. Couple and Family Psychology: Research and Practice, 2(1), 34-44. doi: http://dx.doi.org/10.1037/a0031719

Davis, D. E., Choe, E., Meyers, J., Wade, N., Varjas, K., Gifford, A., \& Worthington, E. L. (2016). Thankful for the little things: a meta-analysis of gratitude interventions. Journal of Counseling Psychology, 63(1), 20-31. doi: http://dx.doi.org/10.1037/cou0000107

Drążkowski, D., Kaczmarek, Ł. D., \& Kashdan, T. B. (2017). Gratitude pays: A weekly gratitude intervention influences monetary decisions, physiological responses, and emotional experiences during a trustrelated social interaction. Personality and Individual Differences, 110, 148-153. doi:

https://doi.org/10.1016/j.paid.2017.01.0 $\underline{43}$

Emmons, R. A. (2007). Thanks! : How the new science of gratitude can make you happier. New York: Houghton Mifflin Company.

Emmons, R. A., \& Stern, R. (2013). Gratitude as a psychotherapeutic intervention. Journal of Clinical Psychology, 69(8), 846-855. doi: http://dx.doi.org/10.1002/jclp.22020

Fitzgerald, P. (1998). Gratitude and justice. Ethics, 109(1), 119-153. doi: http://doi.org/10.1086/233876

Gordon, C. L., \& Baucom, D. H. (2009). Examining the individual within marriage: personal strengths and relationship satisfaction. Personal Relationships, 16(3), 421-435. doi: http://dx.doi.org/10.1111/j.14756811.2009.01231.x

Hirschberger, G., Srivastava, S., Marsh, P., Cowan, C. P., \& Cowan, P. A. (2011). Attachment, marital satisfaction, and divorce during the first fifteen years of parenthood. Personal Relationships, 16(3), 401-420. doi: http://dx.doi.org/10.1111/j.14756811.2009.01230.x.

Lambert, N. M., \& Fincham, F. D. (2011). Expressing gratitude to a partner leads to more relationship maintenance behavior. Emotion, 11(1), 52-60. doi: http://dx.doi.org/10.1037/a0021557

Lambert, N. M., Fincham, F. D., Braithwaite, S. R., Graham, S. M., \& 
Beach, S. R. H. (2009). Can prayer increase gratitude? Psychology of Religion and Spirituality, 1(3), 139-149. doi: http://dx.doi.org/10.1037/a0016731 Linley, P. A., \& Joseph, S. (Eds.). (2004). Positive psychology in practice. Hoboken, NJ: John Wiley \& Sons, Inc.

Listiyandini, R. A., Nathania, A., Syahniar, D., Sonia, L., \&Nadya, R. (2015). Mengukur rasa syukur: Pengembangan model awal skala bersyukur versi Indonesia. Jurnal Psikologi Ulayat, 2(2), 473-496.

Maulina, D. (2015). Pelatihan kebersyukuran untuk meningkatkan kepuasan perkawinan pada istri (Unpublished master's thesis). Faculty of Psychology, Universitas Gadjah Mada, Yogyakarta. Mccullough, M. E., Emmons, R. A., \& Tsang, J.-A. (2002). The grateful disposition: a conceptual and empirical topography. Journal of Personality and Social Psychology, 82(1), 112-127. doi:

http://dx.doi.org/10.1037//0022$\underline{3514.82 .1 .112}$

Mitchell, R. A. (2010). Thankful couples: Examining gratitude and marital happiness at the dyadic level (Unpublished master's thesis). Department of Psychology, University of North Carolina, Chapel Hill.

Ni'mah, E. M. L. (2014). "Menabung Kebahagiaan" sebagai intervensi kebersyukuran terhadap penyesuaian pernikahan (Unpublished master's thesis). Faculty of Psychology, Universitas Gadjah Mada, Yogyakarta.

Olson, D., DeFrain, J., \& Skogrand, L. (2013). Marriages and families: Intimacy, diversity, and strengths. New York:
McGraw-Hill.

Omani-Samani, R., Maroufizadeh, S., Ghareri,A., Amini,P., Navid,B. (2018). Reliability and validity of the Kansas Marital Satisfaction Scale

(KMSS) in infertile people. Middle East Fertility Society Journal, 23 (2): 154-157. doi:

http://dx.doi.org/10.1016/j.mefs.2017.10 .005

Papalia, D., Olds, S., \& Feldman, R. (2008). Human development. New York: McGraw-Hill Education.

Parnell, K. J. (2015). The influence of a couple gratitude intervention on emotions, intimacy, and satisfaction in the relationship (Unpublished doctoral dissertation). Faculty of the Graduate College, University of NebraskaLincoln, Lincoln.

Proulx, C. M., Helms, H. M., \& Buehler, C. (2007). Marital quality and personal well-being: A meta-analysis. Journal of Marriage and Family, 69(3), 576-593. doi: https://doi.org/10.1111/j.17413737.2007.00393.x

Shadish, W. R., Cook, T. D., \& Campbell, D. T. (2002). Experimental and quasiexperimental designs for generalized causal inference. Boston, MA: Houghton, Mifflin and Company.

Stone, E., \& Shackerlford, T. K. (2013). Marital satisfaction. In R. F. Baumeister \& K. . Vohs (Eds.), Encyclopedia of Social Psychology (pp. 541-544). Washington, DC: SAGE Publications, Inc.

Strong, B., DeVault, C., \& Cohen, T. F. (2011). The marriage and family experience: Intimate relationships in a changing society. Belmont: Cengage 
Learning.

Wahyuningsih, H. (2012). Model psikologis kualitas perkawinan pasangan suami istri (Unpublished doctoral dissertation). Faculty of Psychology, Universitas Gadjah Mada, Yogyakarta.

Watkins, P. C. (2014). Gratitude and the good life: Toward a psychology of appreciation. New York: Springer.

Watkins, P. C., Woodward, K., Stone, T., \& Kolts, R. L. (2003). Gratitude and happiness: development of a measure of gratitude, and relationships with subjective well-being. Social Behavior and Personality: An International Journal, 31(5),

431-451.

doi: http://dx.doi.org/10.2224/sbp.2003.31.5. $\underline{431}$

Wood, A. M., Joseph, S., \& Linley, P. A. (2007). Coping style as a psychological resource of grateful people. Journal of Social and Clinical Psychology, 26(9), 1076-1093.

doi:

http://dx.doi.org/10.1521/jscp.2007.26.9 .1076

Zaheri, F., Dolatian, M., Shariati, M., Simbar, M., Ebadi, A., \& Azghadi, S. B. H. (2016). Effective factors in marital satisfaction in perspective of Iranian women and men: A systematic review. Electronic Physician, 8(12), 3369-3377. doi: https://doi.org/10.19082/3369 